\title{
MENJAGA KERAGAMAN EKONOMI RAKYAT \\ DI TENGAH PANDEMI COVID-10 \\ (Suatu kajian Islam untuk Bangsa Indonesia)
}

\author{
Fauzan \\ Sekolah Tinggi Agama Islam Al-Kamal \\ Sarang Rembang Jawa Tengah \\ Email : fauzanstai@gmail.com
}

\begin{abstract}
Abstrak
Masyarakat Indonesia merupakan masyarakat yang beragam, pluralistik, atau multikulturalistik. Kondisi masyarakat ini disebut oleh banyak pakar sebagai wujud kekayaan yang tidak ternilai. Kondisi ini sedang diuji oleh virus Corona atau Covid-19. Pandemi Covid-19 ini membuat banyak pihak dihadapkan pada kekhawatiran, yang diantaranya sebagian memilih jalan sendiri-sendiri untuk menghadapinya, dan bukan jalan kesatuan dalam keragaman. Ketakutan inilah yang tidak dibenarkan dalam ajaran Islam. Islam memerintahkan mereka untuk bersatu atau saling membantu antara satu dengan lainnya. Covid-19 tidak bisa dihadapi sendirian, melainkan membutuhkan kekuatan kebersamaan.
\end{abstract}

Kata kunci: keragaman, Islam, masyarakat, kesatuan, kebersamaan

\section{Abstract}

Indonesian society is a diverse, pluralistic, or multiculturalistic society. This condition of society is referred to by many experts as a form of invaluable wealth. This condition is being tested by Corona or Covid-19 viruses. The Covid-19 pandemic made many parties confronted with concerns, some of which chose their own path to deal with it, and not the path of unity in diversity. This fear is not justified in Islamic teachings. Islam commands them to unite or help one another. Covid-19 can not be faced alone, but requires the strength of togetherness.

Keywords: diversity, Islam, society, unity, togetherness

\section{PENDAHULUAN}

Tidak selalu ujian atau bencana yang datang ke dunia ini bisa dibaca dan dianalisi (diperkirakan) dengan benar dan tepat. Dalam ranah general, bangsa manapun di muka bumi bisa maju, salah satunya ditentukan oleh besaran atau ragam tantangan yang bisa kita hadapi.

Jika tantangan tersebut bisa dijawab atau selesaikan oleh setiap subyek bangsa, hal ini tandanya bangsa tersebur lebih bisa menunjukkan diri dalam prestasi sebagai individu, keluarga, kelompok, atau bangsa dan 
negara. Mereka ditantang untuk membuktikan dirinya sebagai bangsa yang tangguh.

Ketika bangsa Indonesia dan masyarakat dunia sedang diuji dengan virus Corona (Covid-19), maka ujian ini juga layak dibaca atau ditempatkan sebagai bagian dari bencana atau cobaan yang mengingatkan, bahwa mereka atau kita ini dikaruniai hidup oleh Allah SWT untuk membuktikan jika prediket sebagai "khalifah fil ardl" (pemimpin di bumi) memang pantas disandang.

Hal itu menandakan, bahwa seharusnya manusia sebagai makhluk terbaik harus menunjukkan bukan hanya bisa keluar dari serbuan ujian virus Corona, disamping juga tetap mampu memainkan pran sebagai sosok yang bisa melahirkan banyak kreasi yang membuat dunia ini menarik dihuni (dinikmati) dalam segala aspek keindahannya. Kalau kemampuan manusia berhasil ditunjukkan, maka akan banyak perubahan yang terjadi.

Kalau seperti itu, indikasinya kita bukan hanya bisa menaikkan status kita dari negara "lembek" menjadi negara kuat, tetapi juga akan membuat kita mampu menghadapi apapun tantangan, termasuk virus Corona yang membentang. Kita akan bisa melewati (mengalahkan) tantangan demikian, jika kita memang terus berusaha dan menunjukkan progresifitas kapabilitas sebagai bangsa atau "utusan Tuhan" yang tidak mau, apalagi menerima kalah.

Dalam aspenk itulah, sangat tidak logis jika kita sampai merana akibat Corona. Ada beragam dampak yang membuat derita karena Corona adalah wajar, tetapi menunjukkan sikap sebagai bangsa yang terus merana, apalagi putus asa, yang seolah sudah mengalami ketidakberdayaan berkelanjutan adalah kekeliruan sangat besar.

Hal itu menunjukkan, bahwa salah satu persoalan yang dinilai banyak pihak sedang mengkhawatirkan bangsa yang sedang dihadapkan dengan wabah Covid-19 adalah soal ketahanan ekonomi rakyat. Mereka takut rakyat negeri ini akan kehabisan, minimal mengalami krisis ekonomi serius akibat Covid-19. Jika wabah ini berlangsung lama, mereka lebih khawatir lagi dengan ketersediaan sumberdaya ekonomi negara ini.

Tanpa menjalankan strategi dan langkah yang lebih terarah dalam tanggap darurat ekonomi yang nyata atau berlandaskan peta permasalahan ekonomi ynag sebenarnya, bukan tidak mungkin dampak pandemi Covid 19 bakal memicu ancaman kesulitan ekonomi nasional, khususnya rakyat kecil.

Selain itu secara khusus di sektor pangan, barangkali bukan akibat kurangnya stok pangan, atau gangguan logistik dan distribusi, tapi akibat masyarakat yang tidak sanggup lagi membeli bahan pangan, yang nota bene terjadinya rediksi kemampuan ekonomi. Apalagi di lain sisi, sejumlah 
pengusaha juga memberi sinyal bahwa kemampuan keuangan perusahaan mereka untuk bertahan di tengah badai Covid -19 maksimal enam bulan ke depan.

Tanda kalau kita tidak menyerah, diantaranya selalu giat dalam menunjukkan kinerja sebagai subyek bangsa, baik yang berada di lini rakyat biasa maupun khususnya yang sedang berada di zoa elitisme kekuasaan. Bagi yang berada di zona kekuasaan ini, segala modal kekuasaan, dapat digunakan secara benar demi mengentas (menjadi solusi) atas dampak yang menimpa rakyat. Masalahnya, mampukah masyarakat Indonesia, khususnya kalangan elitnya membebaskan negara dari Covid-19?

\section{METODE PENELITIAN}

Dalam penelitian ini, jenisnya adalah penelitian kualitatif dengan Teknik deskriptif analitis. Penelitian ini memusatkan perhatian pada masalah-masalah aktual sebagaimana adanya setelah penelitian ini dilaksanakan ${ }^{1}$ Dalam penelitian kualitatif, peneliti berbaur dalam situasi yang diteliti. Peneliti adalah pengumpul data, orang yang memiliki kesiapan penuh untuk memahami situasi. Sedangkan penelitian deskriptif adalah penelitian yang berusaha menggambarkan kegiatan penelitian ${ }^{2}$ yang dilakukan pada objek tertentu secara jelas dan sistematis, dalam penelitian ini penulis melakukan eksplorasi, menggambarkan dengan tujuan untuk dapat menerangkan dan memprediksi terhadap suatu gejala yang berlaku atas dasar data yang diperoleh di lapangan. ${ }^{3}$ Dalam prosedur pengumpulan data memakai tiga teknik pengumpulan data, yaitu observasi, interview, dan dokumentasi. Sedangkan Analisis data adalah serangkaian kegiatan penelaahan, pengelompokan, sistematisasi, penafsiran dan verifikasi data agar sebuah fenomena memiliki nilai sosial, akademis, dan ilmiah. $^{4}$

\section{PEMBAHASAN}

Berbagai bentuk pesan atau nasihat disampaikan oleh pemerintah dan tokoh-tokoh agama. Mereka mengajak masyarakat dengan tema seperti "bersama melawan Corona", "bersatu melawan Corona", atau "dengan

\footnotetext{
${ }^{1}$ Nana Sudjana dan Ibrahim. Penelitian dan Penilaian Pendidikan. (Bandung: Sinar Baru, 1989). 64.

${ }^{2}$ Nana Syaodih. Metode Penelitian Pendidikan. (Bandung: Remaja Rosdakarya, 2008), 3.

${ }^{3}$ Sukardi. Metodologi Penelitian Pendidikan. (Jakarta: Bumi Aksara, 2009), 14.

${ }^{4}$ Imam Suprayogo dan Tobroni. Metodologi Penelitian Sosio-Agama.

(Bandung: Remaja Rosdakarya, 2001), 191.
} 
bersama, kita bisa menghadapi Corona”. Demikian ini adalah sejumlah imbauan secara moral dan spiritualitas yang sangat serius yang sebenarnya ditujukan pada seluruh elemen bangsa ini agar menyemaikan cinta atau kepedulian pada siapapun, khususnya dari aspek ekonomi bangsa (rakyat).

Tuntutan atau ajakan "bersatu" atau "bersama" itu merupakan pesan moral kebangsaan yang sangat agung, yang menunjukkan, bahwa tidak ada hal mustahil yang tidak bisa diatasi atau diselesaikan jika dilakukan dengan mengutamakan semangat dan aksi bersama atau bersatu, khususnya dalam menghadapi serangan Corona. Negara ini pernah atau berkali-kali menghadapi krisi ekonmi, tetapi faktanya tetap bisa keluar dari masalah. Keragaman sosial, agama, dan khususnya ekonomi mampu membawa kesatuan hidup, sehingga bisa memecahkan masalah serius bangsa.

Nasihat atau pesan pada rakyat memang tidak ukup kalau hanya disampaikan sekali saja. Imbauan penting itu harus disampaikan dan kumandangkan berkali-kali yang kesemua ini berelasi dengan kebinekaan (keragaman) bangsa ini.

Kata-kata seperti "kersama" atau "bersatu" itu dapat diidentikan sebagai kritik, bahwa kita atau bangsa Indonesia selama ini sering kesulitan atau lambat menjawab problem bangsa disebabkan perbedaan (keragaman), sehingga supaya tidak menjadi duri, maka disampaikanlah secara verkelanjutan. Faktor kebinekaan ini membuat sesuatu yang mestinya bukan kemustahilan untuk dikalahkan, akhirnya gagal dimenangkan atau dilaksanakan. Hal inilah yang tidak boleh terjadi pada masa pandemi Covid-19.

Hal itu menunjukkan, bahwa ada tuntutan untuk menyikapi keragaman sebagai kekayaan. Keragaman ekonomi seperi sejumlah orang bisa kaya atau bermodal besar, sementara yang lainnya dalam kondisi miskin, adalah realitas yang harus dikonvergensikan, bukan sebagai dalih untuk memecah belah bangsa.

Sekarang, panggilan cinta datang dari virus Corona. Virus ini mengajak setiap subyek bangsa, apapun agama, politik, budaya, etnis, ekonomi, pendidikan, dan lainnya untuk banyak memberikan cinta pada sesamanya. Hal ini menunjukkan, bagi yang mempunyai keunggulan ekonomi, maka keunggulannya ini harus dimanfaatkan untuk mendampingi atau membebaskan penderitaan yang secara ekonomi tidak mampu.

Kita selama ini masih lebih sering menunjukkan pola sikap dan perilaku yang bercorak merekahkan konstruksi kesatuan dan keharmonisan bangsa. Disharmonisasi sosial masih sering mencuat akibat adanya sikap atau perilaku seseorang atau sekelompok orang yang menghadirkan gaya monologis dan eksklusif yang nota bene menempatkan dirinya dan kelompoklah yang paling benar dan wajib diikuti, sementara seeorang atau 
kelompok lainnya sebagai pihak yang layak dialinasikan atau tidak perlu dukungan kemanusiaan.

Demikian itulah model seseorang dan sekelompok orang yang sejatinya tidak paham kebinekaan, sehingga pemikiran dan perilakunya harus direkonstruksi secara terus menerus. Mereka wajib diedukasikan supaya menjadikan Indonesia tetap sebagai "rumah" besar yang memayungi keragaman etnis, golongan, agama, politik, budaya, dan lainnya, terlebih saat menghadapi serangan Corona ini.

Pengedukasian itu bukan hanya menjadi wujud pengakuan terhadap eksistensi hak keberagaman, tetapi juga sekaligus sebagai bentuk penguatan sisi kemanusiannya. Langkah ini penting sebagai wujud gerakan riil masifikasi atau perluasan kecerdasan nurani berbasis pemedulian kemanusiaan. Filosof Cicero pernah menyatakan, mea mihi conscientia pluris est quam omnium sermo yang maknanya hati nurani saya bernilai lebih banyak daripada semua khotbah. ${ }^{5}$

Cicero secara tidak langsung mengajarkan, bahwa pemosisian model intoleransi dan eksklusifisme sebagai wujud gerakan pembenaran eksklusifitas dan monologis oleh seseorang dan segolongan orang harus dijawab (dikalahkan) dengan memperbanyak pencerdasan nalar dan pembeningan nurani yang diwujudkan dalam aksi-aksi humanitas inklusif.

Pengedukasikan sikap dan perilaku kebinekaan dalam wujud masifikasi aksi-aksi kemanusiaan dalam relasinya dengan Corona ini juga merupakan panggilan pengabdian universalitas terhadap realitas kondisi riil masyarakat Indonesia yang multicultural. Artinya realitas keindonesiaan tidaklah bisa dipaksakan harus berada dalam payung hegemoni keseragaman sehingga saat diuji Corona ini, semua elemen bangsa harus menjadi "pengabdi-pengabdi" totalitas kemanusiannya, terutama dalam mendidik untuk "mengislamisasikan" perilakunya. Syed Sajjad Husain dan Syed Ali Ashraf menyebut kesejatian pendidikan Islam adalah suatu pendidikan yang melatih perasaan murid-murid dengan cara begitu rupa sehingga dalam sikap hidup, tindakan, keputusan, dan pendekatan mereka terhadap segala jenis pengetahuan, mereka dipengaruhi sekali oleh nilai spritual dan sangat sadar akan nilai etis Islam ${ }^{6}$

Kondisi multikultral itu menjadi kekayaan tersendiri masyarakat Indonesia. Jika kekayaan (sumberdaya ekonom) ini diposisikannya sebagai sumberdaya strategis yang sekarang duji Corona, maka berbagai langkah

5 Fahrurkhan Ali, Mari Belajar Filsafat Untuk Kemanusiaan, (Surakarta: Galiacerdas, 2007), 34,

6 Syed Sajjad Husain dan Syed Ali Ashraf, Crisis Muslim Education., Terj. Rahmani Astuti, Krisis Pendidikan Islam, (Bandung: Risalah, 1986), 2. 
pengembangan atau pemajuan HAM (kemanusiaan) tidak sampai mengalami kesulitan.

Atas realitas itu, setiap subyek hidup bermasyarakat dan berbangsa ini justru harus terus menerus dididik atau dibentuk di ranah apapun, seperti dimulai dari keluarga. sekolah dasar hingga perguruan tinggi supaya mereka bukan hanya menjadi manusia-manusia yang rela menjadi subyek penegak hak kemanusiaan dalam kebinekaan, tetapi juga berupaya membentuk dirinya dimanapun dan saat kapanpun (menghadapi Corona) untuk menjadi kekuatan yang militan dalam mewujudkan sakralitas dan fundamentalitas hak kemanusiaan secara meluas.

Militansi kemanusiaan dalam berkebinekaan itu harusnya memang mengalami progresifitas di dada setiap subyek bangsa, pasalnya di ranah meluasnya keberagaman, setiap subyek dituntut menalar dan mengadaptasikan diri secara cerdas seiring dahsyatnya ragam dan banyaknya tantangan (ujian Corona).

Kecerdasan nalar dan etik akan bisa terbaca dalam relasi inklusif dan berkeadaban antar pemeluk agama, produsen budaya, paedagog, pelaku politik, dan khususnya ekonomi (pengusaha). Perbedaan mesti ditoleransi dan didemokratisasi secara rasional dan lapang dada. Artinya perbedaan dalam segala aspek kehidupan mesti disikapi secara rasional dan konstruktif untuk mewujudkan kesatuan dalam keberagaman.

Hak kebinekaan merupakan hak yang dijamin oleh sejumlah norma di dunia. Di negeri ini, setiap pemeluk agama misalnya dijamin hak beragamanya secara konstitusional, sehingga setiap pemeluk agama berkewajiban menegakkan hak kebinekaan ketika pemeluk agama lainnya menjalankan aktifitas spiritualitasnya.

Secara konstitusionalitas, Pasal 28E ayat (1) Undang-undang Dasar 1945 menggariskan, setiap orang bebas memeluk agama dan beribadat menurut agamanya. Dalam ayat (2) berbunyi, setiap orang berhak atas kebebasan meyakini kepercayaan, menyatakan pikiran, dan sikap, sesuai dengan hati nuraninya. Dasar konstiusi ini mengatur realitas keberagaman atau kebinekaan di tengah masyarakat, yang harus dijunjung tinggi oleh siapapun.

Ketentuan secara konstitusionalitas tersebut juga sudah jelas menunjukkan, bahwa di negara ini setiap orang berhak bebas menjalankan dan mengembangkan kebinekaannya, khususnya dalam menjalankan doktrin agamanya, baik yang beragama Islam, Kristen, Budha, Hindu, Konghucu, maupun keyakinan lainnya. Siapapun dan kekuatan apapun dilarang dan dari golongan manapun keras memproduksi pola kebencian dan "keserakahan" (lebih sering di sektor perekonomian) dalam menjalankan aktifitasnya, termasuk dalam membangun ekonominya, sehingga sebagai bukti dirinya 
menjalankan pesan konstitusi, setiap orang, kelompok, dan organisasi apapun harus menunjukkan sikap dan aksi-aksi kemanusiaan.

Seharusnya seseorang atau sekelompok orang dari pihak atau golongan apapun berusaha terus menerus mengembangkan dirinya sebagai subyek pelindung dan pengadvokasi hak keberagaman. Progresifitas ini menuntutnya guna menciptakan dan membumikan kultur saling memanusiakan atau mengapresiasi antar masing-masing orang dalam keragamannya, khususnya saat ada banyak "saudaranya" yang mengalami kesulitan, terutamaka kesulitan ekonomi di tengah terjangan pandemi Corona ini.

Kalau prinsip mulia itu bisa diwujudkan, maka negeri ini akan menjadi kuat dan progresif dalam kultur kebinekaan dan sedikit demi sedikit mampu mereduksi masifikasi Corona, setidaknya meminimalisasi beban kesulitan ekonomi "saudaranya" yang terhambat mendapatkan instrumen medis (kesehatan) yang harganya dijadikan obyek kompetisi di kalangan "rezim" pasar. Jika dalam menghadapi Corona ini, masing-masing subyek sosial, politik, agama, budaya, dan lain sebagainya "berkompetisi" dalam menjalankan, menabur dan menyuburkan kebajikan (kemanusiaan) untuk semua, maka jargon "bersama melawan Corona" akan bisa terwujud atau berhasil membumi di tengah masyarakat.

Saat negara masih saja belum beranjak statusnya dari negara "lembek" (meminjam istilah atau label dari Sosiolog Gunnar Myrdal), ${ }^{7}$ apalagi terasanya atau terbacanya pada saat menghadapi ujian virus Corona, maka ini mengindikasikan kalau masyarakatnya atau kita memang belum berkeinginan kuat atau belum benar-benar menunjukkan nyali ata keberanian secara maksimal untuk menjadikan bangsa atau negara ini menjadi bangsa atau negara yang maju.

Kita bisa menjadi sekumpulan manusia-manusia yang beragam, dalam hal ini sebagai kesatuan subyek bangsa yang berhasil, mencapai prestasi hebat, atau menikmati kebernegaraan yang sejahtera secara ekonomi dan di aspek kesehatan adalah sesuai dengan tingkat usaha-usaha yang bersifat serius yang kita tunjukkan. Kalau kita tidak menunjukkan keseriusan misalnya dalam "mengurus" masalah bangsa, memang dampak rakyat merana bisa terjadi dan bahkan boleh jadi berkepanjangan.

Kekayaan berbentuk kebinekaan di berbagai sisi kehidupan tidak selalu dimiliki oleh setiap bangsa di dunia, meski di setiap bangsa ini, selalu ada kebinekaan atau keragaman. Bangsa Indonesia memiliki kebinekaan

${ }^{7}$ Abdul Wahid, dkk, Kebijakan Publik dan Etika Pemerintahan, (Jakarta: Nirmana Media, 2019), 45. 
akibat banyak aspek yang mempengaruhinya. ${ }^{8}$ Kekayaan besar yang dimiliki bangsa Indonesia ini merupakan anugerah Tuhan yang tidak ternilai. Untuk memuliakan anugerah besarNya ini, tergantung bagaimana manusia Indonesia mensyukurinya. Keragaman budaya, agama, sosial, etnis, dan lainnya tidak perlu dipertentangkan, Karena masing-masing mengandung keistimewaan.

Nama seperti multi etnis, multi budaya, dan lainnya identik dengan Indonesia, yang kesemua itu justru membuat bangsa ini menarik. Bangsa Indonesia selain harus menunjukkan rasa bangganya, juga harus menunjukkan sikap dan perilaku melindunginya. Terkadang kita baru merasa mempunyai kekayaan besar ketika ada bangsa lain yang mengusik dan berusaha memilikinya

Sangat ironis atau sungguh lucu jika misalnya masih ada sekumpulan kaum elitis yang hanya pasip atau tidak banyak menunjukka mental kinerja utama atau seriusnya di saat bangsa menghadapi ujian virus Corona. Atas hal ini, logis jika muncul gugatan, apa sebenarnya yang sedang dicari oleh elitis ini dalam relasinya dengan amanat rakyat dan realitas problem bangsa (ditimpa pandemi Covid-19)?

Kemajuan dan kesejahteraan hanya bisa diraih dengan kerja keras atau berusaha dengan mengerahkan segala kemampuan. Tidak ada rakyat yang akan atau ditimpa kondisi merana sepanjang elitismenya memang sungguhsungguh mengerahkan segala kemauan dan kemampuannya untuk menjaga kemaslahatan rakyat.

Mereka itu bisa menjadi lokomotif perubahan dalam kehidupannya, baik di ranah domestik atau di publiknya jika tidak memilih jalur eksklusifitas gaya hidup. Di negara-negara manapun yang rakyatnya bisa kuat menghadapi ujian adalah ditentukan oleh teladan yang diberikan oleh para pemimpinnya (elitisme kekuasaan) yang jujur dalam menjalankan amanat dan selalu aktif berada di barisan kepentingan rakyat. Rakyat tidak sering dibiarkan berjuang melawan kesulitannya sendiri, melainkan terus diberikan pemecahan masalah secara lebih mudah.

Kondisi merana seharusnya tidak perlu ditemukan akibat Corona, jika saja semua subyek bangsa, khususnya di kalangan elitisnya benar-benar sangat serius membuktikan kalau dirinya "pengabdi" totalitas kepentingan rakyat secara profesional, dan bukan berjalan sendiri-sendiri (secara individualistik).

Untuk membaca realitas itu marilah kita perhatikan firman Allah yang terdapat dalam surat Al Hujuraat ayat 10 : Sesungguhnya orang-orang mukmin itu bersaudara, maka ciptakanlah kerukunan dan jalinlah rasa

\footnotetext{
${ }^{8}$ Kholilurrahman Saad, Kewajiban Bela Negara: Menjaga Kebinekaan Indonesia, (Bandung: Kalimas, 2015), 3.
} 
persaudaraan diantara kalian dan bertaqwalah kepada Allah, niscaya kalian akan mendapat limpahan rahmatNya.

Berdasarkan ayat tersebut kita mendapatkan pelajaran bahwa rahmat Allah itu akan diberikan kepada orang-orang yang bertaqwa kepadaNya, dan orang yang suka menjalin tali persaudaraan, saling mengasihi, serta suka menciptakan kerukunan diantara sesama manusia. Sebaliknya orang yang suka menebarkan kebencian dan permusuhan akan terputus dari rahmat Allah.

Makna terputus dari rahmat Allah berarti jauh dari kedamaian. Jauh dari kedamaian berarti hidup dalam kebencian, permusuhan, atau setidaktidaknya gagal menikmati atmosfir keharmonisan dan kedamaian. Sebaliknya siapa yang sibuk menabur kasih diantara kita, berarti akan menuai banyak kerahmatan dalam hidupnya.

Logis jika ajaran agama menuntut kita supaya kita berusaha maksimal mengerahkan kemampuan untuk menjadi hamba-hamba Allah yang memiliki rasa kasih sayang kepada sesama, selalu mengupayakan kedamaian di tengah-tengah masyarakat, serta mengedepankan rasa persaudaraan dalam berbagai aktivitas kehidupan, diantaranya aktifitas ekonomi. Kondisi perekonomian sesamanya harus dijaga oleh saudaranya, meski berbeda agama, sosial, budaya, dan lainnya.

McCormick (1983) menyebutkan empat model multikulturalisme dalam konteks pembentukan suatu bangsa sebagaimana berikut: pertama; model melting pot, dalam pengertian peleburan etnisitas dan budaya menjadi sebuah bangsa baru, sehingga ciri-ciri etnisitas dan budaya lama yang membentuk kesatuan bangsa itu menjadi hilang, kedua; model assimilation, yaitu suatu pandangan yang membenarkan iliminasi perbedaan-perbedaan yang ada dan membaur dengan budaya kelompok yang dominan. Biasanya warna budaya kelompok dominan tersebut yang masih mudah dikenali meskipun sudah berkurang, sebaliknya budaya kelompok lemah akan menjadi kabur dan hilang, ketiga; model salad bowi, yang memandang keharusan setiap individu atau kelompok dalam suatu masyarakat harus menghormati keragaman kultural (cultural diversity) yang berasal dari etnis, budaya, agama, bahasa, dan wilayah dimana individu dan kelompok berasal. Pada saat yang sama mendukung kesepakatan yang telah di setujui bersama untuk bersatu dan saling menghormati dalam satu wadah dan hidup berdampingan secara damai. Bangsa Indonesia mengikuti model ketiga ini dengan semboyan "Bhineka Tunggal Ika", keempat; model open nation, suatu pandangan masyarakat terbuka, masyarakat dengan segala keberagamannya dibebaskan mengambil cara yang dikehendaki dalam 
membentuk suatu bangsa. ${ }^{9}$ Cara yang digunakan dalam membentuk atau menguksi suatu bangsa memang bisa berbeda-beda sesuai dengan karakter, budaya, agama, ekonomi, atau keyakinan masing-masing bangsa. Cara pun bisa disesuaikan dengan tingkat kedinamikaan atau kondisi tertentu masingmasing dalam bangsa ini, sehingga ketika keragamannya mengalami dinamika, otomatis akan menuntut penyesuaian. ${ }^{10}$

Hal itu menunjukkan, bahwa bukan perdamaian yang direkayasa, atau sikap persaudaraan yang pura-pura, namun rasa bersaudara yang benarbenar keluar dari ketulusan atau kebeningan hati nurani, karena hal itulah yang dapat mendatangkan limpahan rahmat Allah SWT. Persaudaraan tidak pura-pura bermakna persaudaraan yang berasal dari saling memahami dan memproteksi apa yang dirasakan oleh saudaranya. Kesulitan ekonomi yang dirasakan oleh saudaranya harus menjadi perhatian saudaranya yang diberikan keunggulan ekonomi atau yang berstatus kelas atas (upper class).

Rasa kebencian, rasa dendam dan permusuhan serta segala tindakan yang berakibat kerusakan di muka bumi, tidak akan mendatangkan kedamaian. Suasana damai hanya bisa dibangun oleh manusia yang hatinya bersih dan suka menabur kasih di antara sesama manusia. Jika kasih ini ditabur dan "disuburkan" sekarang, apalagi saat negeri sedang diuji oleh Corona, makna istimewa akan besar pengaruhnya terhadap konstruksi persaudaraan.

Berkaitan dengan rasa kasih di tengah ujian Corona itu, menarik kita cermati sabda Rasulullah saw. dalam sebuah hadits yang diriwayatkan oleh Imam Thabrani dan Hakim mengingatkan kita "kasihilah siapa dan apa saja yang ada di bumi, niscaya (Allah dan MalaikatNya) yang ada di langit akan mengasihi kalian".

Hadis tersebut memberi pelajaran berharga kepada kita, bahwa kita diperintahkan menghidupkan dan memarakkan jiwa kasih, karena dari jiwa kasih ini, bangunan kehidupan kemasyarakatan akan diwarnai oleh keberkahan (kesejahteraan, kedamaian, kesehatan, dan keselamatan). Nilai edukatif yang diajarkan Nabi itu menekankan pada aspek memberikan perhatian (kasih) untuk sesama tanpa melihat (mempertimbangkan) aspek tertentu seperti perbedaan agama dan budaya.

Di era pandemi Covid-19 sekarang ini, idealnya setiap pelaku sosial, politik, agama, dan segenap segmen bangsa yang berseberangan jalan dan kepentingan untuk menyatukan dan mensucikan serta menguatkan bangunan kehidupan kemasyarakatan dan kebangsaan ini, sehingga mereka bisa

\footnotetext{
${ }^{9}$ Muhammad Tholchah Hasan, Pendidikan Multikuralisme sebagai Opsi Penanggulangan Radikalisme, (Malang: Universitas Islam Malang, 2016), 45.

${ }^{10}$ Roudhotul Jannah, "Menyemai Kedamaian di Tengah Kebinekaan" , Pusatk Kajian Kebangsaan dan Kebudayaan, Surabaya, 25 Juni 2015, 11.
} 
menyatukan langkah guna memakmurkan republik ini di segala aspeknya. Penyatuan langkah ini merupakan wujud konvergensi antara keyakinan dengan langkah (aksi) nyata dalam menjalankan pekerjaan besar di tengah masyarakat, yakni problem serius ynag sedang dihadapi masyarakat.

\section{KESIMPULAN}

Setiap masyarakat atau bangsa di muka bumi ini mempunyai keunggulanya masing-masing. Masyarakat Indonesia merupakan masyarakat yang lebih beragam, pluralistik, atau multikulturalistik lebih spesifik dibandingkan dengan masyarakat atau bangsa lain. Kondisi masyarakat ini disebut oleh banyak pakar sebagai wujud kekayaan yang tidak ternilai. Kondisi ini sedang diuji oleh virus Corona atau Covid-19. Begutu pula kondisi ekonominya, yang identic dengan keragaman di sektor lainnya, sehingga tidak perlu dipertentangkan, apalagi menimbulkan masalah baru seperti radikalisme dan fundamentalisme.

Dalam ranah perkembangan globak, pandemi Covid-19 itu telah membuat banyak pihak dihadapkan pada kekhawatiran atau ketakutan yang serius, yang diantaranya sebagian memilih jalan sendiri-sendiri untuk menghadapinya, dan bukan jalan kesatuan dalam keragaman. Ketakutan inilah yang tidak dibenarkan dalam ajaran Islam. Islam memerintahkan mereka untuk bersatu atau saling membantu antara satu dengan lainnya. Covid-19 tidak bisa dihadapi sendirian, melainkan membutuhkan kekuatan kebersamaan dan saling tolong menolong.

\section{DAFTAR PUSTAKA}

\section{Buku}

Abdul Wahid, dkk, 2019, Kebijakan Publik dan Etika Pemerintahan, Jakarta: Nirmana Media.

Fahrurkhan Ali, 2007, Mari Belajar Filsafat Untuk Kemanusiaan, Surakarta: Galiacerdas.

Imam Suprayogo dan Tobroni. 2001, Metodologi Penelitian SosioAgama. Bandung: Remaja Rosdakarya.

Kholilurrahman Saad, 2015, Kewajiban Bela Negara: Menjaga Kebinekaan Indonesia, Bandung: Kalimas.

Muhammad Tholchah Hasan, 2016, Pendidikan Multikuralisme sebagai

Opsi Penanggulangan Radikalisme, Malang: Universitas Islam Malang.

Nana Sudjana dan Ibrahim. 1989, Penelitian dan Penilaian Pendidikan. Bandung: Sinar Baru. 
Nana Syaodih. 2008, Metode Penelitian Pendidikan. Bandung: Remaja Rosdakarya.

Sukardi. 2009, Metodologi Penelitian Pendidikan. Jakarta: Bumi Aksara.

Syed Sajjad Husain dan Syed Ali Ashraf, 1986, Crisis Muslim Education., Terj. Rahmani Astuti, Krisis Pendidikan Islam, Bandung: Risalah,.

\section{Makalah}

Roudhotul Jannah, "Menyemai Kedamaian di Tengah Kebinekaan”, Pusatk Kajian Kebangsaan dan Kebudayaan, Surabaya, 25 Juni 2015 